\title{
Attention, Interest, Desire, and Action Distribution of Universitas Airlangga Students Visiting the Dental and Oral Health Services
}

\author{
Darmawan Setijanto, Nilna Nur Putri, Taufan Bramantoro, Titiek Berniyanti, Agung Sosiawan, \\ Retno Palupi and Gilang Rasuna Sabdho Wening \\ Department of Dental Public Health, Faculty of Dental Medicine, Universitas Airlangga \\ darmawansetijanto@fkg.unair.co.id
}

Keywords: $\quad$ AIDA, Dental and Oral Health Services, Visits.

\begin{abstract}
From the results of RISKESDAS data, of $25.9 \%$ who had oral and dental problems in the last 12 months, only $31.1 \%$ received dental care from medical personnel, while the other $68.9 \%$ did not undergo any treatment. Overall EMD (Effective Medical Demand) in Indonesia is only 8.1\%. EMD in East Java reached only 8.6\%, while the active number of students of Universitas Airlangga were recorded to number as many as 30,430 students, but only $8.6 \%$ ever visited the dental service in PLK UNAIR. UNAIR students' inclination to visit dental and oral health services can be observed by using the AIDA stages, so that healthcare practitioners can make appropriate interventions for UNAIR students to increase their visits to dental and oral health services. To determine the AIDA distribution (Attenton, Interest, Desire, Action) of Universitas Airlangga students visiting dental and oral health services, a cross-sectional study with 126 students of Universitas Airlangga was conducted. This research was an observasional descriptive study. The samples were selected by stratified random sampling. The research instrument was a validated questionnaire. Results: the AIDA distribution of Universitas Airlangga students visiting dental and oral health services gave results regarding stage of Attention (52.3\%), Interest (47.6\%), Desire (56.3\%), and Action (48.4\%). More than half of the respondents were in the stage of Attention and Desire but more than half of the respondents had not reached the Interest and Action stages of visiting dental and oral health services. The largest distribution of Universitas Airlangga students were found to be at the stage of Desire.
\end{abstract}

\section{INTRODUCTION}

Of the $25.9 \%$ from the results of RISKESDAS data who had oral and dental problems in the last 12 months, only $31.1 \%$ received dental care from medical personnel, while the other $68.9 \%$ did not undergo any treatment. Overall EMD (Effective Medical Demand) in Indonesia is only $8.1 \%$. EMD in East Java reached only $8.6 \%{ }^{1}$

According to a preliminary survey that researchers conducted in PLK Unair in the last 6 months, the active students of Universitas Airlangga were recorded to number as many as 30,430 students, but only $8.6 \%$ ever visited dental services in PLK UNAIR

People in Indonesia tend to ignore the condition of their dental health as a whole. The description of the number of students visiting dental poly PLK UNIAR can be an indication that students of Universitas Airlangga also tend to ignore the condition of their teeth and mouths. Dental care is considered not very important although it has very vital benefits in supporting health and mien 2 .

Based on data from students of Universitas Airlangga they visit PLK Unair at quite a low rate, and there are various factors related to the decision to visit dental and oral health services. Therefore, the writer wanted to do research to know the distribution of AIDA (Attenton, Interest, Desire, and Action) of Universitas Airlangga students visiting the dental and oral health services to increase visitors from PLK Unair, and to know and make the right intervention for each student who is in each stage.

Before this descriptive research, there was no about the AIDA stage of a person visiting the dental and oral health services.

\section{MATERIALS AND METHODS}

This research was observational descriptive research that aimed to determine the distribution of AIDA 
(Attention, Interest, Desire, and Action) of the students of Universitas Airlangga visiting dental and oral health services. The sample numbered 126 students selected by stratified random sampling. The sample composition in this study consisted of 56 male subjects and 70 female subjects, from stratum one to stratum three with an age range of 19 to 56 years.

This research was conducted on 13 faculties and one postgraduate program at Universitas Airlangga Surabaya. This research began by assigning respondents who agreed to fill out the questionnaire. The questionnaire concerned sickness perception, respondents' knowledge, Attention, Interest, Desire, and Action amounting to 45 questions, and about demographic data. The data that was processed, with AIDA cross-tabulated using SPSS 17 application for some risk factors.

\section{RESULTS}

This research was conducted in all faculties at Universitas Airlangga Surabaya with respondents selected by stratified random sampling. The number of respondents in each faculty was proportioned according to the number of students. The total respondents were 126 students. This research was conducted for two months, running from September 30, 2016 until November 16, 2016. The collected data was then recapitulated so that data obtained in the form of the demographic characteristics of respondents (gender, age, strata, study program), pain perception, knowledge about dental and mouth services, and AIDA (Attention, Interest, Desire and Action) of the students of Universitas Airlangga Surabaya visiting dental and oral health services.

Table 1: AIDA Distribution of Universitas Airlangga Students Visiting Dental and Oral Health Services.

\begin{tabular}{|l|c|c|c|c|}
\hline \multirow{2}{*}{ AIDA } & \multicolumn{2}{|c|}{ Yes } & \multicolumn{2}{c|}{ No } \\
\cline { 2 - 5 } & n & \% & n & \% \\
\hline Attention & 66 & 52,4 & 60 & 47,6 \\
\hline Interest & 60 & 47,6 & 66 & 52,4 \\
\hline Desire & 71 & 56,3 & 55 & 43,7 \\
\hline Action & 61 & 48,4 & 65 & 51,6 \\
\hline
\end{tabular}

Table 1 shows that the highest AIDA percentage of Universitas Airlangga students visiting dental and oral health services are at the Desire $(56.3 \%)$ and not Interest stage $(52,4 \%)$.

Table 2: Distribution of Respondents on Attention Stage of Visiting Dental and Oral Health Services.

\begin{tabular}{ll} 
Attention & Total \\
\hline Yes No
\end{tabular}

\begin{tabular}{|c|c|c|c|c|}
\hline \multirow[b]{2}{*}{ Gender } & Male & $\begin{array}{l}24 \\
(42.9 \%) \\
\end{array}$ & $\begin{array}{l}32 \\
(57.1 \%) \\
\end{array}$ & 56 \\
\hline & Female & $\begin{array}{l}42 \\
(60 \%)\end{array}$ & $\begin{array}{l}28 \\
(40 \%) \\
\end{array}$ & 70 \\
\hline \multirow{3}{*}{ Age } & $19-31$ & $\begin{array}{l}57 \\
(49.6 \%) \\
\end{array}$ & $\begin{array}{l}58 \\
(50.4 \%) \\
\end{array}$ & 115 \\
\hline & $32-44$ & $\begin{array}{l}6 \\
(85.7 \%) \\
\end{array}$ & $\begin{array}{l}1 \\
(14.3 \%) \\
\end{array}$ & 7 \\
\hline & $45-56$ & $\begin{array}{l}3 \\
(75 \%)\end{array}$ & $\begin{array}{l}1 \\
(25 \%) \\
\end{array}$ & 4 \\
\hline \multirow{3}{*}{ Strata } & S1 & $\begin{array}{l}42 \\
(48.3 \%) \\
\end{array}$ & $\begin{array}{l}45 \\
(51.7 \%) \\
\end{array}$ & 87 \\
\hline & S2 & $\begin{array}{l}17 \\
(58.6 \%) \\
\end{array}$ & $\begin{array}{l}12 \\
(41.4 \%) \\
\end{array}$ & 29 \\
\hline & S3 & $\begin{array}{l}7 \\
(70 \%) \\
\end{array}$ & $\begin{array}{l}3 \\
(30 \%) \\
\end{array}$ & 10 \\
\hline \multirow[b]{2}{*}{$\begin{array}{l}\text { Study } \\
\text { program }\end{array}$} & Health & 25 & 7 & 32 \\
\hline & $\begin{array}{l}\text { program } \\
\text { Non Health } \\
\text { program }\end{array}$ & $\begin{array}{l}\frac{(78.1 \%)}{41} \\
(43.6 \%)\end{array}$ & $\begin{array}{l}(21.9 \%) \\
53 \\
(56.4 \%)\end{array}$ & 94 \\
\hline \multirow{2}{*}{$\begin{array}{l}\text { Tootache } \\
\text { and mouth } \\
\text { perception }\end{array}$} & Under average & $\begin{array}{l}31 \\
(48.4 \%)\end{array}$ & $\begin{array}{l}33 \\
(51.6 \%)\end{array}$ & 64 \\
\hline & Above average & $\begin{array}{l}35 \\
(56.6 \%)\end{array}$ & $\begin{array}{l}27 \\
(43.4 \%)\end{array}$ & 62 \\
\hline \multirow[b]{2}{*}{ Knowledge } & Under average & $\begin{array}{l}27 \\
(35.5 \%) \\
\end{array}$ & $\begin{array}{l}49 \\
(64.5 \%) \\
\end{array}$ & 76 \\
\hline & Above average & $\begin{array}{l}39 \\
(78 \%)\end{array}$ & $\begin{array}{l}11 \\
(22 \%)\end{array}$ & 50 \\
\hline
\end{tabular}

Table 2 shows that the higher Attention is in female students $(60 \%)$ with an age range of 32-44 years $(85.7 \%)$, S3 students $(70 \%)$, background of health study program $(78.1 \%)$ with a higher perception of toothache and mouth pain $(56.6 \%)$ and higher knowledge (78\%). 
Table 3: Distribution of Respondents at the Interest Stage of Visiting Dental and Oral Health Services.

\begin{tabular}{llll}
\hline & \multicolumn{1}{l}{ Desire } & Total \\
\cline { 2 - 4 } & Yes & No & \\
\hline Male & 25 & 31 & \\
& $(44.6 \%)$ & $(55.4 \%)$ & 56 \\
\hline
\end{tabular}

Gender

\begin{tabular}{llll} 
Female & 35 & 35 & 70 \\
& $(50 \%)$ & $(50 \%)$ & \\
\hline & 54 & 61 & 115 \\
\hline $\mathbf{1 9 - 3 1}$ & $(46.9 \%)$ & $(53.1 \%)$ & \\
\hline & 2 & 5
\end{tabular}

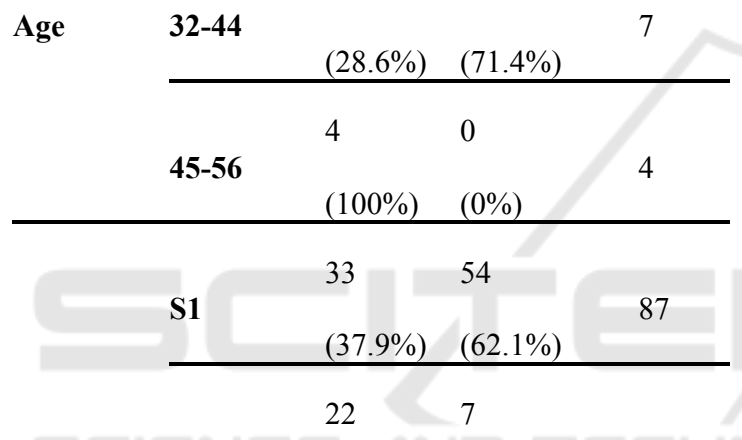

\begin{tabular}{lllll} 
Strata & S2 & & & 29 \\
& & $(75.9 \%)$ & $(24.1 \%)$ & \\
\cline { 2 - 4 } & & 5 & 5 & 10 \\
& S3 & $(50 \%)$ & $(50 \%)$ & \\
\hline
\end{tabular}

Health $\quad 17 \quad 15$

\begin{tabular}{lllll} 
Study & program & $(53.1 \%)$ & $(46.9 \%)$ & \\
program & Non Health43 & 51 & \\
& program & $(45.7 \%)$ & $(54.3 \%)$ & 94 \\
\hline \multirow{5}{*}{ Tootache } & $\begin{array}{l}\text { Under } \\
\text { average }\end{array}$ & 22 & 42 & \\
& & $(34.4 \%)$ & $(65.6 \%)$ & 64
\end{tabular}

$\begin{array}{rlll}\text { and mouth } & & & \\ \text { perception } & 38 & 24 & \\ \begin{array}{l}\text { Above } \\ \text { average }\end{array} & (61.3 \%) & (38.7 \%) & 62\end{array}$

\begin{tabular}{cllll}
\hline & $\begin{array}{l}\text { Under } \\
\text { average }\end{array}$ & 32 & 44 & 76 \\
\cline { 2 - 4 } & & & & \\
Knowledge & $(42.1 \%)$ & $(57.9 \%)$ & \\
& $\begin{array}{l}\text { Above } \\
\text { average }\end{array}$ & 28 & 22 & 50 \\
\hline
\end{tabular}

Table 3 shows that the higher interest is in female students $(50 \%)$ with an age range of $45-56$ years (100\%), S2 students $(75,9 \%)$, background of health study program $(53,1 \%)$ with a higher perception of toothache and mouth pain $(61.3 \%)$ and higher knowledge (56\%).

Table 4: Distribution of Respondents at the Desire Stage of Visiting the Dental and Oral Health Services.

\begin{tabular}{|c|c|c|c|c|}
\hline & & Action & & Total \\
\hline & & Yes & No & \\
\hline & & 30 & 26 & \\
\hline & Male & & & 56 \\
\hline & & $(53.6 \%)$ & $(46.4 \%)$ & \\
\hline Gender & & & & \\
\hline & & 41 & 29 & \\
\hline & Female & & & 70 \\
\hline & - & $(58.6 \%)$ & $(41.4 \%)$ & \\
\hline & 2 & 64 & 51 & \\
\hline & 19-31 & & $4-111$ & 115 \\
\hline & & $(55.6 \%)$ & $(44.4 \%)$ & \\
\hline Age & & 4 & 3 & \\
\hline & $32-44$ & & & 7 \\
\hline & & $(57.1 \%)$ & $(42.9 \%)$ & \\
\hline & & 3 & 1 & \\
\hline & $45-50$ & & & 4 \\
\hline & & $(56.3 \%)$ & $(25 \%)$ & \\
\hline & & 45 & 42 & \\
\hline & S1 & & & 87 \\
\hline & & $(51.7 \%)$ & $(48.3 \%)$ & \\
\hline & & 21 & 8 & \\
\hline Strata & S2 & & & 29 \\
\hline & & $(72.4 \%)$ & $(27.6 \%)$ & \\
\hline & & 5 & 5 & \\
\hline & S3 & & & 10 \\
\hline & & $(50 \%)$ & $(50 \%)$ & \\
\hline & Health & 43 & 12 & \\
\hline & & & & 55 \\
\hline Study & program & $(78.2 \%)$ & $(21.8 \%)$ & \\
\hline program & $\begin{array}{l}\text { Non } \\
\text { Health }\end{array}$ & 51 & 20 & \\
\hline & & & & 71 \\
\hline & program & $(71.8 \%)$ & $(28.2 \%)$ & \\
\hline
\end{tabular}




\begin{tabular}{lllll}
\multirow{2}{*}{ Tootache } & $\begin{array}{l}\text { Under } \\
\text { average }\end{array}$ & 28 & 36 & 64 \\
and mouth & & $(43.7 \%)$ & $(56.3 \%)$ & \\
\cline { 2 - 5 } perception & $\begin{array}{l}\text { Above } \\
\text { average }\end{array}$ & 43 & 19 & \\
\hline & $\begin{array}{l}\text { Under } \\
\text { average }\end{array}$ & 41 & 35 & 62 \\
\cline { 2 - 5 } Knowledge & $(69.4 \%)$ & $(30.6 \%)$ & 76 \\
\cline { 2 - 5 } & $\begin{array}{l}\text { Above } \\
\text { average }\end{array}$ & 30 & $(46 \%)$ & \\
\hline
\end{tabular}

Table 4 shows that the higher Desire is in female students $(58.6 \%)$ with an age range of $32-44$ years (57.1\%), S2 students (72.4\%), background of health studies program $(78,2 \%)$ with a higher perception of toothache and mouth pain $(69.4 \%)$ and higher knowledge $(60 \%)$.

Table 5. Distribution of Respondents at the Action Stage of Visiting Dental and Oral Health Services

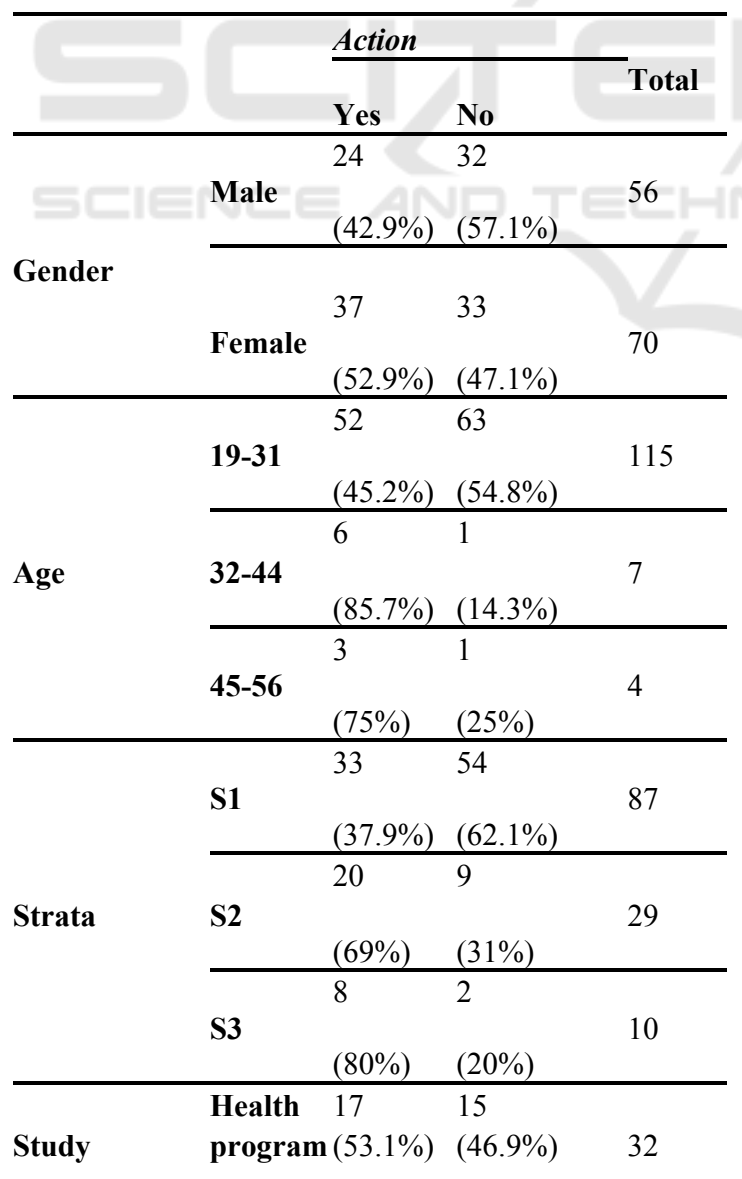

\begin{tabular}{|c|c|c|c|c|}
\hline program & $\begin{array}{l}\text { Non } \\
\text { Health } \\
\text { progran }\end{array}$ & $\begin{array}{l}44 \\
(46.8 \%) \\
\end{array}$ & $\begin{array}{l}50 \\
(53.2 \%) \\
\end{array}$ & 94 \\
\hline $\begin{array}{l}\text { Tootache } \\
\text { and mouth }\end{array}$ & $\begin{array}{l}\text { Under } \\
\text { average }\end{array}$ & $\begin{array}{l}24 \\
(37.5 \%)\end{array}$ & $\begin{array}{l}40 \\
(62.5 \%)\end{array}$ & 64 \\
\hline perception & $\begin{array}{l}\text { Above } \\
\text { average }\end{array}$ & $\begin{array}{l}37 \\
(59.7 \%)\end{array}$ & $\begin{array}{l}25 \\
\quad(40.3 \%)\end{array}$ & 62 \\
\hline \multirow[b]{2}{*}{ Knowledge } & $\begin{array}{l}\text { Under } \\
\text { average }\end{array}$ & $\begin{array}{l}31 \\
(40.8 \%) \\
\end{array}$ & $\begin{array}{l}45 \\
(59.2 \%) \\
\end{array}$ & 76 \\
\hline & $\begin{array}{l}\text { Above } \\
\text { average }\end{array}$ & $\begin{array}{l}30 \\
(60 \%)\end{array}$ & $\begin{array}{l}20 \\
(40 \%)\end{array}$ & 50 \\
\hline
\end{tabular}

Table 5 shows that the higher Action stage was in female students $(52,9 \%)$ with an age range of 32-44 years $(85.7 \%)$, S3 students $(80 \%)$, background of health study program $(53,1 \%) \%$ with higher perception of toothache and mouth pain $(59.7 \%)$ and higher knowledge (60\%).

\section{DISCUSSION}

After the analysis of the AIDA (Attention, Interest, Desire, Action) stages of Universitas Airlangga students visiting dental and oral health services, the results show that $52.4 \%$ of respondents had Attention to visit dental and oral health services. Someone's attention to dental and oral health services was measured to determine how someone's knowledge about the presence of dental and oral services are negative or positive.

A knowledgeable person is more likely to focus on the most relevant information to evaluate the advantages and disadvantages of visits to dental and oral health services. Attention is formed as a result of a person's information search. Thus, it can be concluded that Attention is closely related to the person's innovation and activeness. Attention measured by knowledge includes knowledge of the characteristics of right oral health services, dental hygienists authorized to provide care, the benefits of dental and oral health services, and the existence of PLK Unair as a dental and mouth health service located in campus environment 3,6.

The percentage of Universitas Airlangga's nonAttention students being as much as $47.6 \%$ is due to 
the lack of knowledge about dental and oral health services, seen but the knowledge of the respondents who consider that the nurses may offer care when actually they are not be allowed to do so based on Pasal 73 ayat (2). But nowadays, there is a rise of nurses and dentists who do activities that violate existing regulations.

Interest is the stage when someone begins to assess the innovation of dental and oral health services because this stage is in the affective domain. In other words, at this stage, someone forms his own perception about the dental and oral health services. Interest is in the affective stage of a person's visit to dental and oral health services so as to shape one's perceptions and attitudes toward it. The results showed that $47.6 \%$ of students are in the Interest stage. Interest is measured by preferences for dental and oral health services, conformity of dental and oral healthcare characteristics with self-understanding, oral and dental healthcare information, perceptions of dental and oral health service characteristics, and perceptions about the benefits of dental and oral health services 3,6 .

One of the factors of a person's low interest in dental and oral health services is because $46.9 \%$ of respondents assume the oral cavity is not the most important organ of the body. This is because Universitas Airlangga students tend to ignore the condition of the teeth and mouth. So, dental care is considered not very important although it has very vital benefits in supporting health and mien.

Desire of visits to dental and oral health services is one of the main factors for determining whether or not to visit. The results showed $56.3 \%$ of respondents are at the Desire stage. Desire of visits to dental and oral health services is one of the main factors for determining to act or not. Desire is characterized by a willingness to visit dental and oral health services, the willingness of respondents to pay maintenance at a higher price to obtain treatment from qualified and adequate medical personnel, recommending oral and dental services to others, willingness to reduce visits to dental nurses, save the contact information of dental and oral health services, and willingness to compare between types of dental and oral health services 3,6 .

A higher desire indicates that respondents are interested in visiting dental and oral health services; it was seen that for one of the higher factors, $88.9 \%$ of the respondents considered the price factor, although to the dentist it is more expensive than dental practice, but the respondents were still willing to visit the dentist for reasons of quality. In addition, $77.8 \%$ of the respondents were also willing to invite others to visit dental and oral health services, indicating that the respondents were trying to influence others to want to go to dental and oral health services because they feel that by visiting dental and oral health services they can get a lot of profit.

The results showed that $51.6 \%$ of respondents preferred not to take Action. The actions of respondents were measured by visits to dental and oral health services over the past six months, the willingness to avoid inappropriate visits to dental and oral care, consistency of visits to dental and oral health services in the future, and information seeking the latest on dental and oral health services.

Although most students were in the Attention and Desire stages of visits to dental and oral health services, the respondents who acted was less than $50 \%$. These results show that Action is not enough and just as with Attention and Desire, there are other factors that affect the lower percentage of the Interest stage while the percentage of Desire is high enough; it is possible that the actual respondents did not like or were not interested in paying a visit to dental and oral health services but circumstances required them to seek care in dental and oral health services so that Desire tends to be higher than Interest. It can be said that the majority of students were in the Desire group but are not visitors to dental and oral health services. It is indicated by the research result of higher percentage of respondents' desire but the percentage of Action tended to be lower. It is possible that this situation happened because the respondents were afraid to go to a dentist though they know what the benefits are and what they need. Another possibility is that these respondents did not act regarding adequate dental and oral services, as seen in the results of the study whereby $5.56 \%$ were still going to dentists and $3.2 \%$ to dental nurses. This is because the knowledge of some Universitas Airlangga students about adequate dental and oral care facilities is still quite low, as seen in one item in the questionnaire which mentioned that $70.6 \%$ assumed that dental nurses include dental professionals who are allowed to do maintenance.

Besides the routine visits also still being quite low, there are $46.8 \%$ of respondents who will only go to the dentist if there are complaints but not regular visits to the dentist at least every 6 months. It indicates that the Action performed is not based on knowledge, so it becomes unsustainable and manifests a negative action.

In the AIDA distribution seen from the gender aspect, the results of the study showed that female students were higher in Attention, Interest, Desire, and Action scores than male students for visits to 
dental and oral health services. This is because women tend to have more shame and interest in the opposite sex so they strive more to look beautiful and clean. This is in accordance with research conducted by Zetu which states that women have more positive behavior toward oral hygiene. In addition, a higher level of female anxiety leads women to further reduce their fears by seeking preventive and curative measures recommended by health practitioners than men, thus increasing their visits to dental and oral care.

The results of AIDA distribution of visits to dental and oral health services by age show that those in the age range of 45-56 years tend to have a higher level of Interest and Desire but in Action dominated by the age range of 32-44 years. According to Kotler, the age factor can affect a person's behavior, but the need is often adjusted for age. Age is the standard of a person's psychological maturity. With increasing age a person's knowledge and experience are more numerous. Utilization of dental and oral health services is also affected by age.

The results of the study showed that the attention and action score of S3 students is higher, while Interest score and Desire of S2 students is higher. The higher the level of education the greater the knowledge of a person about disease and it will affect the awareness of people in taking action to treat their disease. In addition, one's experience grows more and more as their education increases. The higher the education of a person, the better their understanding will affect their attitude 11. This is in accordance with the results of research indicating that the higher strata of the AIDA stage are dominated by S2 and S3 students.

In the study program aspect, it can be seen that the AIDA distribution of Universitas Airlangga students indicates that a study program with a health background has a higher AIDA score in regard to visiting dental and oral health services than nonhealth background courses. According to Mansur, a person with a background in health has greater knowledge about oral healthcare information, and tends to have higher knowledge to address his health problems 12 . This is consistent with research showing that the study programs dominating at the Attention stage, Interest, Desire, and Action are study programs with a health background, i.e. pharmacy, dentistry and nursing. Study programs with a health background have more knowledge and information in regard to visits to dental and oral health services and more awareness about the health of the oral cavity than non-health study programs.
The distribution of AIDA (Attention, Interest, Desire and Action) based on the perception of toothache and mouth pain felt by respondents showed that respondents who have a higher perception of tooth and mouth pain are more likely to have Attention, Interest, Desire, and High actions for visits to dental and oral health services. According to Achmad, perception is the process by which a person chooses, organizes and interprets information. Perception depends not only on physical stimulation but also on stimuli related to the surrounding environment and the individual state in question. The public perception of disease will vary by individual 13. This is in line with the study that the higher the perception of toothache and mouth pain that someone has felt, the higher the percentage in the AIDA stage.

So, if the respondent knows the perception of toothache and mouth pain that has been felt correctly he will always take advantage of dental and oral health services and not wait for severe illness, but immediately search for dental and oral health services. This is in contrast to respondents who have a perception of toothache and mouth pain that has been felt wrongly who will delay the need to obtain treatment and so usually try to treat themselves by buying drugs in the shop, traditional medicine or by waiting for a severe illness before visiting dental and oral health services.

In the AIDA distribution based on the respondents' knowledge level, the results show that respondents who have a higher level of knowledge tend to have more Attention, Interest, Desire, and higher Action to visit dental and oral health services. A person who has higher knowledge will be better in making decisions, more precise and efficient in processing information, and be able to utilize the information well, and knowledge or cognition is a very important domain to make someone do something.

Knowledge includes basic factors in Green's healthy behavior model. Every individual with access to dental and oral health services has information about dental and oral health services. Knowledge of what services are obtained when using a service will affect a person when taking advantage of oral and dental services or not.

From the result of the frequency of visits by Universitas Airlangga students to dental and oral health services, most visit dental and mouth health services when there is no complaint just based on routine checking every 6 months. According to Anderson, there are several health trust models in which each individual utilizes health services depending on three factors including predisposing 
factors, enabling characteristics, and need characteristics. In other words, the need is the basis and the direct stimulus for using health services, when the predisposing and enabling levels are present. Hence people often only visit when there are complaints that are felt.

The results showed that choice of care type of Universitas Airlangga students when visiting dental and oral health services, most visits are for scaling $(49.2 \%)$ and $34.1 \%$ restorative treatment. This is likely because Universitas Airlangga students have started to care about the importance of their oral hygiene by taking preventive action of scaling.

The research results show that with regard to the type of dental and oral health services in the form of private dental practice, $39.7 \%$ are more preferred by Universitas Airlangga students in terms of dental and oral care than other types of services; only $27 \%$ of Universitas Airlangga students visited the PLK Unair and $18.25 \%$ visited RSGM. According to Wijono, the quality of dental and oral health services from the point of view of the patient is the quality of service, meaning empathy, respect, and concern for their needs, so the service must be appropriate for the needs of the patient and provided in a friendly manner. Someone who is not satisfied with the services provided may not return to use the service in the future.

\section{REFERENCES}

Achmad, Zein. 2009. Aplikasi Pemasaran dan Salesmanship. Jakarta: Mitra Wacana Media.

Badan Penelitian dan Pengembangan Kesehatan Kementerian Kesehatan RI. 2013. Riset Kesehatan Dasar 2013. Jakarta: Badan Penelitian dan Pengembangan Kesehatan Kemenkes RI. Pp. 110-1, 119.

Faroq I, Ali S. 2015. A cross Sectional Study of gender differences in dental anxiety prevailing in the students of a Pakistani dental collage. The Saudi J of Dent Research. Chapter 6. pp. 215.

Kebijakan Kesehatan, Fakultas Kesehatan Masyarakat Universitas Sam Ratulangi. Pp 2-3.

Kotler, P., and Keller, K.L., 2008. Manajemen Pemasaran. Jilid Satu, Edisi Keduabelas, Cetakan Ketiga. Penerbit Indeks. pp. 178, 214.

Lee, J.S., Hsu, L.T., Han, H., Kim, Y. 2010. Understanding how consumers view green hotels: how a green hotel's green image can influence behavioral intentions. Journal of Sustainable Tourism, 18. pp. 901-14
Madunde KJ, Pelealu FJ, Kawatu P. 2013. FaktorFaktor yang Berhubungan dengan Pemanfaatan Pelayanan Kesehatan di Puskesmas Kema Kecamatan Kema Kabupaten Minahasa Utara. Manado : Bidang Minat Administrasi.

Mansur, 2005. Pendidikan Anak Usia Dini dalam Islam. Yogyakarta: Pustaka Pelajar.

Naomi, N. 2011. Analisis Perilaku Konsumsi Prouk Ramah Lingkungan pada Remaja: Aplikasi Model AIDA (Attention, Interets, Desire, dan Action). Bogor: Institut Pertanian Bogor. pp. 53-87.

Notoatmodjo, Soekidjo. 2003. Pendidikan Kesehatan dan Perilaku Kesehatan. Jakarta: Rineka Cipta.

Notoatmodjo, Soekidjo. 2010. Ilmu Perilaku Kesehatan. Jakarta: Rineka Cipta. Pp. 26-33.

Pangemanan, J., Afriyanti, R., Pallar, S. 2015. Hubungan antara Perilaku Merokok dengan Kejadian Penyakit Jantung Koroner. Jurnal eClinic (eCl), Vol.3, No 1, Januari-April 2015. pp 3.

Pintauli S, Melur T. 2004. Hubungan tingkat pendidikan dan skor DMF-T pada ibu-ibu rumah tangga berusia 20-45 tahun di Kecamatan Medan Tuntungan. Dentika dent J. 9(2). pp. 78-83.

Pratiwi, D. 2007. Gigi Sehat Merawat Gigi Seharihari. Jakarta: Kompas. pp. 11.

Prayoga DS. 2008. Analisis Pelaksanaan Promosi Rumah Sakit Islam Surabaya Jemursari berdasarkan Konsep AIDA. Surabaya : Fakultas Kesehatan Masyarakat Unair. Pp. 7-8.

Rogers, E. M. 2003. Difussion of Innovations. $5^{\text {th }}$ ed. New York: Free Press.

Sumarwan, Ujang. 2011. Riset Pemasaran dan Konsumen: Panduan Riset dan Kajian: Kepuasan, Perilaku Pembelian, Gaya Hidup, Loyalitas dan Persepsi Resiko. Bogor: PT Penerbit IPB Press.

Sunaryo. 2002. Psikologi untuk Perawatan. Jakarta: Penerbit Buku Kedokteran. Konsep dan Teori Perilaku. Pp. 25.

Wahyuni NS. 2012. Faktor-faktor yang Berhubungan dengan Pemanfaatan Layanan Kesehatan di Puskesmas Sumber Rejo Kota Balikpapan Provinsi Kalimantan Timur Tahun 2012. Depok: Universitas Indonesia. pp. 18.

Wijono D. 1997. Manajemen Kepemimpinan dan Organisasi Kesehatan. Surabaya: Universitas Airlangga Press.

Zetu I, Zetu L, Dogaru CB, Duta C, Dumitrescu AL. 2014. Gender variation inpsycological factor as defined by the theory of planned of oral hygiene behaviors. J Procedia-Soc and Behav Sci. 127. p. 353-7. 